\title{
Liquid Phase Morphology Control of ZnO Nanowires, Ellipse Particles, Hexagonal Rods, and Particle in Aqueous Solutions
}

\author{
Yoshitake Masuda, ${ }^{1,2}$ Naoto Kinoshita, ${ }^{2}$ and Kunihito Koumoto ${ }^{2}$ \\ ${ }^{1}$ Advanced Manufacturing Research Institute (AMRI), National Institute of Advanced Industrial Science and Technology (AIST), \\ 2266-98 Anagahora, Shimoshidami, Moriyama-ku, Nagoya 463-8560, Japan \\ ${ }^{2}$ Graduate School of Engineering, Nagoya University, Nagoya 464-8603, Japan
}

Correspondence should be addressed to Yoshitake Masuda, masuda-y@aist.go.jp

Received 31 August 2011; Accepted 18 October 2011

Academic Editors: C. A. Charitidis, H.-C. Hsu, and B. R. Kimball

Copyright (C) 2012 Yoshitake Masuda et al. This is an open access article distributed under the Creative Commons Attribution License, which permits unrestricted use, distribution, and reproduction in any medium, provided the original work is properly cited.

Liquid phase morphology control of $\mathrm{ZnO}$ crystals was realized with simple aqueous solution system. ZnO nanowires were successfully fabricated at $50^{\circ} \mathrm{C}$. They were over $50 \mu \mathrm{m}$ in length and about $100 \mathrm{~nm}$ in width. Aspect ratio was estimated to be over 500. They had no branches and were obtained without aggregations. Curved nano-wires clearly indicated high flexibility and high mechanical strength. Additionally, ellipse particles, hexagonal rods and particles were fabricated in the solutions. Morphology, crystal growth speed, and preferred growth faces were well-controlled by precise adjustment of growth conditions.

\section{Introduction}

Metal oxides have been used for electronic devices, optoelectronic device, and so forth. They will further expand beyond the present borders of research area. Especially, expectations for metal oxide nanostructures have increased recently for future applications. Syntheses of novel metal oxide nanostructures and development of their applications are under intense investigation [1-8]. Special issues [9], reviews [1013], and books [14] on applications of metal oxide nanostructures have received a great response.

$\mathrm{ZnO}$ has attracted much attention as varistors [15], piezoelectric devices [16], electroacoustic transducers [17], and highly transparent conducting windows for solar cells, displays [18], vacuum fluorescent displays (VFDs) [19], field emission displays (FEDs) [20], electroluminescent displays (ELDs) [21], UV light-emitting diodes (LEDs), laser diodes [22], and gas sensors [23, 24], dye-sensitized solar cells [2529], and molecular sensors [30].

Novel $\mathrm{ZnO}$ nanostructures are eagerly anticipated for the applications [31-34]. $\mathrm{ZnO}$ nanowires especially are required for luminescent devices, dye-sensitized solar cells and high sensitive sensors. The nanowires have high electrical conductivity along the longer direction. They have large surface area due to high aspect ratio of the shape. High flexibility and high mechanical strength are required to apply for the devices.

Recently, several $\mathrm{ZnO}$ nano-/microstructures were prepared in the solutions [34-39]. Patterning of them was realized on self-assembled monolayers (SAMs) [35]. Hydrophobic surface of SAMs accelerated deposition of $\mathrm{ZnO}$ nanostructures rather than hydrophilic silanol group surfaces [35]. These studies contributed development of future $\mathrm{ZnO}$ devices.

In this study, $\mathrm{ZnO}$ nanowires were developed in aqueous solutions. Anisotropic crystal growth of $\mathrm{ZnO}$ was well-controlled by precise adjustment of solution conditions. Additionally, ellipse particles, hexagonal rods, and particles were fabricated.

\section{Experimental Details}

Octadecyltrichlorosilane (OTS, $\mathrm{C}_{18} \mathrm{H}_{37} \mathrm{SiCl}_{3}$, Acros Organics), anhydrous toluene (Aldrich Chemical Co., Inc.), zinc acetate $\left(\mathrm{Zn}\left(\mathrm{CH}_{3} \mathrm{COO}\right)_{2}\right.$, Kishida Chemical Co., Ltd.), ammonia ( $28 \%$ solution, Kishida), $\mathrm{NaOH}, \mathrm{HCI}$, ethanol, and acetone were used as received. Distilled water was used as a solvent. 
An Si wafer (p-type Si [100], NK Platz Co., Ltd.) was sonicated for $10 \mathrm{~min}$ in water, ethanol, or acetone, in that order. It was exposed for $15 \mathrm{~min}$ to UV light $(184.9 \mathrm{~nm}$ and $253.7 \mathrm{~nm}$ ) (low-pressure mercury lamp $200 \mathrm{~W}$, PL21-200, $15 \mathrm{~mW} / \mathrm{cm}^{2}$ for $254 \mathrm{~nm}$, SEN Lights Co.) to clean the surface. UV light which has been used in this study (PL21-200) had stronger power than that we used in former studies (NLUV253, Nippon Laser and Electronics Lab.) [40-44]. SAMs of octadecyltrichlorosilane (OTS, $\mathrm{C}_{18} \mathrm{H}_{37} \mathrm{SiCl}_{3}$ ) were prepared by immersing Si substrates in anhydrous toluene (Aldrich Chemical Co., Inc.) solutions containing 1 vol\% OTS (Acros Organics) for $15 \mathrm{~min}$ under an $\mathrm{N}_{2}$ atmosphere. The substrates with the SAMs were baked at $120^{\circ} \mathrm{C}$ for $5 \mathrm{~min}$ to remove residual solvents and promote chemisorption of the SAMs.

Morphology of $\mathrm{ZnO}$ was evaluated with a scanning electron microscope (SEM; S-3000N, Hitachi, Ltd.). Crystal structure of $\mathrm{ZnO}$ was evaluated with an X-ray diffractometer (XRD; RINT-2100, Rigaku, in-plane X-ray diffraction profiles) with $\mathrm{CuK} \alpha$ radiation $(40 \mathrm{kV}, 30 \mathrm{~mA})$ and $\mathrm{Ni}$ filter plus a graphite monochromator.

\section{Results and Discussion}

\subsection{Synthesis of $\mathrm{ZnO}$ in Aqueous Solutions}

(1) Wires. Zinc acetate $\left(\mathrm{Zn}\left(\mathrm{CH}_{3} \mathrm{COO}\right)_{2}, 1.375 \mathrm{~g}\right)$ was dissolved into water of $100 \mathrm{~mL}$ at $50^{\circ} \mathrm{C}$. Ammonia (28\% solution, Kishida, $910 \mathrm{~mL}$ ) was then added as complexing agent with stirring to be $\left[\mathrm{NH}_{3}\right] /[\mathrm{Zn}]=2.0$. The solutions showed $\mathrm{pH}=6.99$ at $1 \mathrm{~min}$ after addition of ammonia. The substrates were immersed in the solutions at bottom up for $3 \mathrm{~h}$. The $\mathrm{pH}$ of the solutions was still $\mathrm{pH}=6.99$ at $3 \mathrm{~h}$ after immersion of the substrates.

(2) Ellipse Particles. The solutions were diluted by 4\% (concentration: 1/25) for fabrication of ellipse particles.

(3) Hexagonal Rods. The solutions were diluted by $20 \%$ (concentration: 1/5) for fabrication of hexagonal rods. HCI was added to control $\mathrm{pH}$.

(4) Particles. The solutions were diluted by $20 \%$ (concentration: 1/5) for fabrication of particles. $\mathrm{NaOH}$ was added to control pH.

$\mathrm{ZnO}$ was formed in the aqueous solutions as follows:

$$
\begin{gathered}
2 \mathrm{NH}_{3}+2 \mathrm{H}_{2} \mathrm{O} \rightleftarrows 2 \mathrm{NH}_{4}{ }^{+}+2 \mathrm{OH}^{-} \\
\mathrm{Zn}\left(\mathrm{CH}_{3} \mathrm{COO}\right)_{2}+4 \mathrm{NH}_{4}{ }^{+} \rightleftarrows \mathrm{Zn}\left(\mathrm{NH}_{3}\right)_{4}{ }^{2+}+2 \mathrm{CH}_{3} \mathrm{COOH} \\
\mathrm{H}_{2} \mathrm{O} \rightleftarrows \mathrm{OH}^{-}+\mathrm{H}^{+} \\
\mathrm{Zn}\left(\mathrm{NH}_{3}\right)_{4}{ }^{2+}+2 \mathrm{OH}^{-} \longrightarrow \mathrm{ZnO}+\mathrm{H}_{2} \mathrm{O}+4 \mathrm{NH}_{3}
\end{gathered}
$$

Zinc acetate solutions were transparent. The solutions became slightly white after addition of ammonia. High ion concentration proceeded formation of $\mathrm{ZnO}$. The particles were formed in the solutions by consumption of ions. Supersaturation degree decreased with the decrease of ion concentrations. The solutions became transparent after a few hours.

(1) Wires. The substrates were rinsed with distilled water and dried in air after immersion. They were evaluated with SEM and XRD. XRD showed that precipitated nano-wires were single phase of $\mathrm{ZnO}$ without additional phases. Many $\mathrm{ZnO}$ nano-wires were observed on the substrates (Figures 1(a)$1(\mathrm{~d}))$. Length was over $50 \mu \mathrm{m}$. Width was about $100 \mathrm{~nm}$. Aspect ratio was estimated to be over $500(=50 \mu \mathrm{m} / 100 \mathrm{~nm})$. Some nanowires curved in top right region of Figure 1(a). Magnified image was shown as Figure 1(b). Radius of the curves was about $1.77 \mu \mathrm{m}$ (Figure 1(b)). It indicated high flexibility and high mechanical strength of the nanowires. They grew along $c$-axis of wurtzite crystal structure. High crystallinity allowed forming 1D structure with uniform width, long length, high flexibility, and high strength. Morphology and size in different areas were shown in Figure 1(c). Small amount of the nanowires deposited on a substrate (Figure 1(d)).This image indicated that the nano-wires were not aggregated and had no branches. They were obtained as separated nanowires. For comparison, $\mathrm{ZnO}$ 1D structures were prepared on fluorine doped tin oxide substrates in aqueous solutions. The solutions contained zinc nitrate hexahydrate $\left(\mathrm{Zn}\left(\mathrm{NO}_{3}\right)_{2} \cdot 6 \mathrm{H}_{2} \mathrm{O}, 15 \mathrm{mM}\right)$ and ethylenediamine $\left(\mathrm{H}_{2} \mathrm{NCH}_{2} \mathrm{CH}_{2} \mathrm{NH}_{2}, 15 \mathrm{mM}\right)$. They were kept at $60^{\circ} \mathrm{C}$ for $6 \mathrm{~h}$ (Figure 2) [45]. Electron diffraction pattern indicated that the structure was a single crystal of $\mathrm{ZnO}$. Lengthwise direction was parallel to $c$-axis of $\mathrm{ZnO}$. Anisotropic crystal growth of $\mathrm{ZnO}$ along $c$-axis caused anisotropic $1 \mathrm{D}$ structure.

(2) Ellipse Particles. Zinc acetate (0.055 g) was dissolved into water of $100 \mathrm{~mL}$ at $50^{\circ} \mathrm{C}$. Ammonia $(36.4 \mathrm{~mL})$ was then added as complexing agent with stirring to be $\left[\mathrm{NH}_{3}\right] /[\mathrm{Zn}]=2.0$. Concentrations of zinc acetate and ammonia were $1 / 25$ of the solution for nanowires. The solutions had low ion concentrations and low supersaturation degree. These induced slow crystallization speed. The solutions showed $\mathrm{pH}=7.49$ at $1 \mathrm{~min}$ after addition of ammonia. The substrates were immersed in the solutions at bottom up for $3 \mathrm{~h}$. The $\mathrm{pH}$ of the solutions was $\mathrm{pH}=6.87$ at $3 \mathrm{~h}$ after immersion of the substrates.

XRD showed that precipitated ellipse particles were single phase of $\mathrm{ZnO}$. Any additional phase was not detected. Many $\mathrm{ZnO}$ ellipse particles were observed on the substrates (Figure 3(a)). They were about $800 \mathrm{~nm}$ in length and $400 \mathrm{~nm}$ in width. Aspect ratio was estimated to be $2(=800 \mathrm{~nm} /$ $400 \mathrm{~nm}$ ). The ellipse particle had two sharp tips and rounded body. For comparison, similar ellipse particles were obtained in our previous study [35]. The previous ellipse particles had more rounded tips.

(3) Hexagonal Rods. HCI (1.0 mL) was added into water of $100 \mathrm{~mL}$ at $50^{\circ} \mathrm{C}$. Zinc acetate $(0.275 \mathrm{~g})$ and ammonia $(182 \mathrm{~mL})$ were then added with stirring to be $\left[\mathrm{NH}_{3}\right] /[\mathrm{Zn}]=$ 2.0. Concentrations of zinc acetate and ammonia were $1 / 5$ of the solution for nanowires. The solutions showed $\mathrm{pH}=6.87$ 


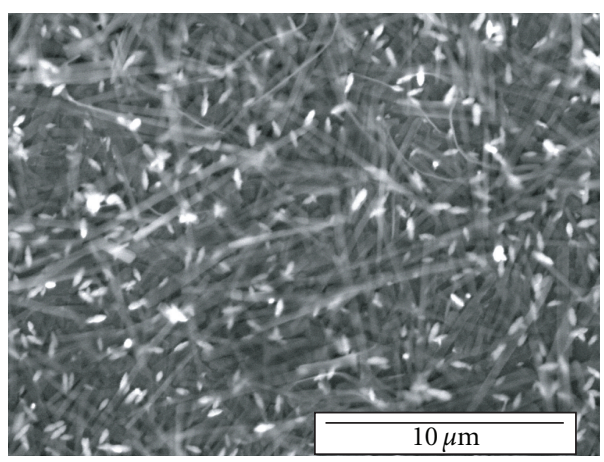

(a) $\mathrm{ZnO}$ nano-wires

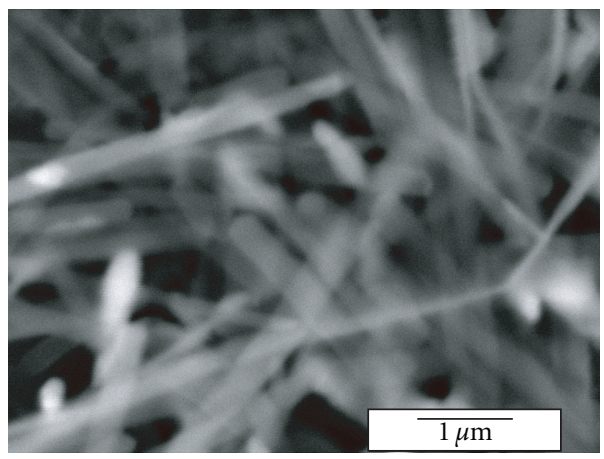

(c) $\mathrm{ZnO}$ nano-wires

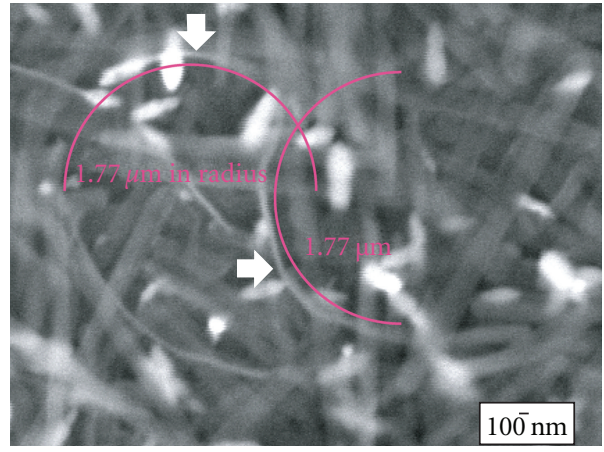

(b) $\mathrm{ZnO}$ nano-wires

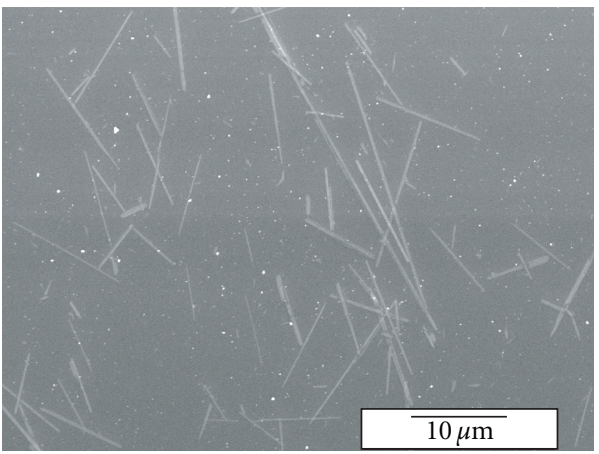

(d) $\mathrm{ZnO}$ nano-wires

FIGURE 1: SEM micrographs of ZnO nanowires. (a) Some nanowires in top right region curved. (b,c) Magnified area of (a) showing morphology of the wires. (d) Separated straight wires on a substrate. This image indicated that the nano-wires were not aggregated and had no branches.
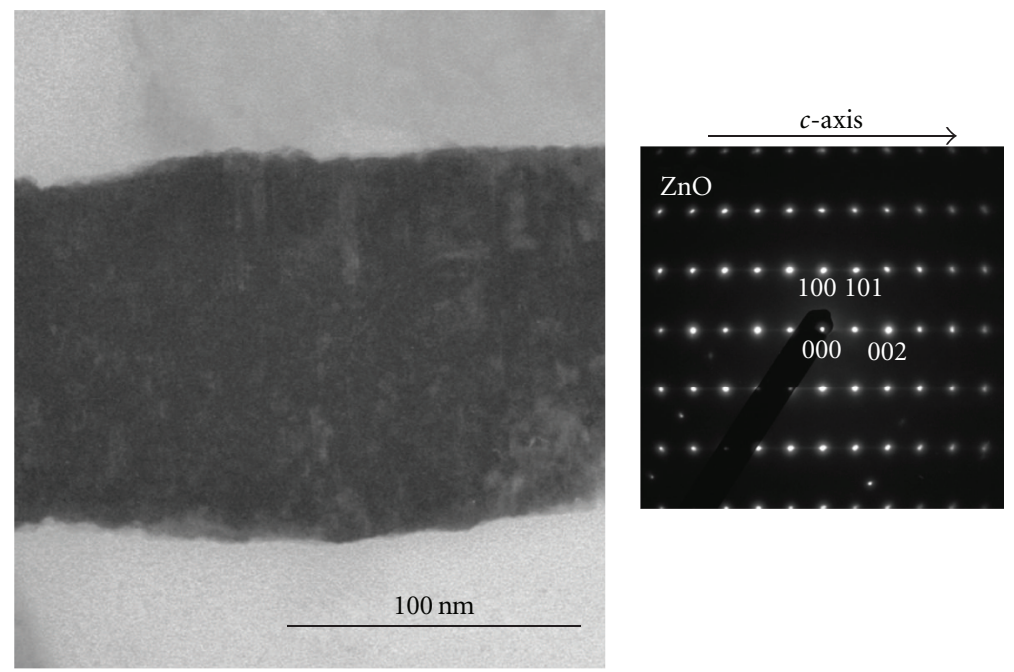

Figure 2: TEM micrograph and electron diffraction pattern of $\mathrm{ZnO} 1 \mathrm{D}$ structure.

at 1 min after addition of ammonia. The substrates were immersed in the solutions at bottom up for $3 \mathrm{~h}$. The $\mathrm{pH}$ of the solutions was $\mathrm{pH}=6.72$ at $3 \mathrm{~h}$ after immersion of the substrates.

XRD showed that precipitated hexagonal rods were single phase of $\mathrm{ZnO}$ without additional phases. Many $\mathrm{ZnO}$ hexagonal rods were observed on the substrates (Figure 3(b)). They were about $500 \mathrm{~nm}$ in length and $200 \mathrm{~nm}$ in width.
Aspect ratio was estimated to be $2.5(=500 \mathrm{~nm} / 200 \mathrm{~nm})$. For comparison, hexagonal cylinder particles were also prepared in our previous studies $[35,36]$. The aspect ratio and sizes were slightly different due to difference in synthesis conditions.

(4) Particles. $\mathrm{NaOH}(1.0 \mathrm{~mL})$ was added into water of $100 \mathrm{~mL}$ at $50^{\circ} \mathrm{C}$. Zinc acetate $(0.275 \mathrm{~g})$ and ammonia $(182 \mathrm{~mL})$ were 


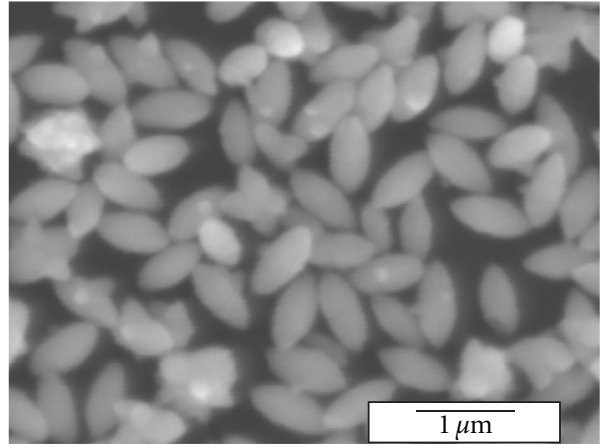

(a) ZnO ellipse particles

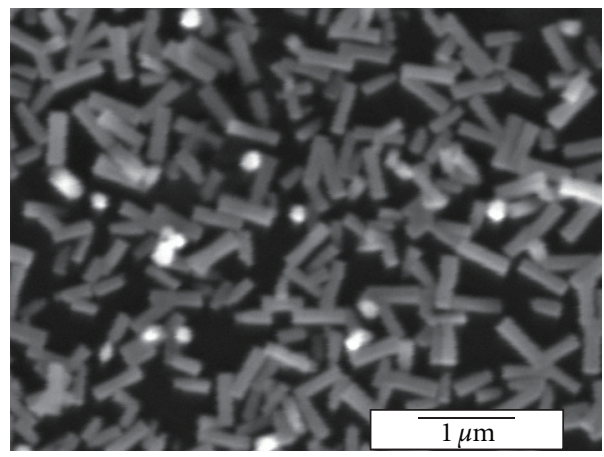

(b) $\mathrm{ZnO}$ hexagonal rods

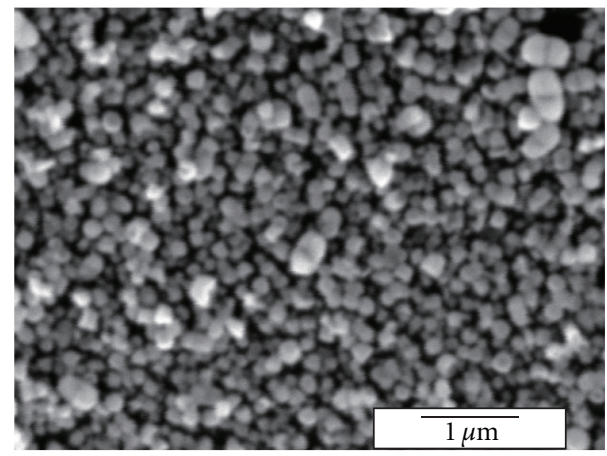

(c) $\mathrm{ZnO}$ particles

Figure 3: SEM micrographs of (a) ZnO ellipse particles, (b) ZnO hexagonal rods, and (c) ZnO particles.

then added with stirring to be $\left[\mathrm{NH}_{3}\right] /[\mathrm{Zn}]=2.0$. Concentrations of zinc acetate and ammonia were same to those of the solution for hexagonal rods. These solutions showed $\mathrm{pH}=$ 7.39 at $1 \mathrm{~min}$ after addition of ammonia. The substrates were immersed in the solutions at bottom up for $3 \mathrm{~h}$. The $\mathrm{pH}$ of the solutions was $\mathrm{pH}=6.91$ at $3 \mathrm{~h}$ after immersion of the substrates. The $\mathrm{pH}$ of the solutions was higher than that of the solution for hexagonal rods due to the addition of $\mathrm{NaOH}$. $\mathrm{XRD}$ showed that precipitated particles were single phase of $\mathrm{ZnO}$ without additional phases. Many $\mathrm{ZnO}$ particles were observed on the substrates (Figure 3(c)). They were about $20 \mathrm{~nm}$ in size. High $\mathrm{pH}$ of the solutions would decrease aspect ratio of hexagonal rods to form particles.

\section{Conclusions}

$\mathrm{ZnO}$ nanowires were successfully fabricated in aqueous solutions at ordinary temperature. They were over $50 \mu \mathrm{m}$ in length and about $100 \mathrm{~nm}$ in width. Aspect ratio was estimated to be over 500. They had no branches and were obtained without aggregations. Curved nanowires clearly indicated high flexibility and high mechanical strength. They can be applied to next-generation $\mathrm{ZnO}$ devices. Additionally, ellipse particles, hexagonal rods, and particles were obtained. The solution conditions had large affects to crystal growth of $\mathrm{ZnO}$. The knowledge obtained in this study will contribute to the development of morphology control of metal oxides.

\section{References}

[1] L. Tang, M. Salamon, and M. R. D. Guire, "Cerium oxide thin films on solid oxide fuel cell anodes," Science of Advanced Materials, vol. 2, no. 1, pp. 79-89, 2010.

[2] D. Chu, Y.-P. Zeng, D. Jiang, and Y. Masuda, "Room temperature ferromagnetism in transition metal doped $\mathrm{TiO}_{2}$ nanowires," Science of Advanced Materials, vol. 1, no. 3, pp. 227-229, 2009.

[3] T. Kawai, H. Takahashi, Y. Matsushima, T. Ogata, and H. Unuma, "Evaluation of photocatalytic activity of $\mathrm{TiO}_{2}$ thin films by spin-trap ESR spectroscopy," Science of Advanced Materials, vol. 2, no. 1, pp. 74-78, 2010.

[4] Y. Masuda, T. Ohji, and K. Kato, "Multineedle $\mathrm{TiO}_{2}$ nanostructures, self-assembled surface coatings, and their novel properties," Crystal Growth and Design, vol. 10, no. 2, pp. 913922, 2010.

[5] Y. Masudaa and K. Katoa, "Tin oxide coating on polytetrafluoroethylene films in aqueous solutions," Polymers for Advanced Technologies, vol. 21, no. 3, pp. 211-215, 2010.

[6] M. Inada, K. Mizue, N. Enomoto, and J. Hojo, "Thermal stability of rutile $\mathrm{TiO}_{2}$ with high specific surface area synthesized by self-hydrolysis process," Science of Advanced Materials, vol. 2, no. 1, pp. 102-106, 2010.

[7] Y. Tokunaga, H. Uchiyama, Y. Oaki, and H. Imai, "Specific photocatalytic performance of nanostructured rutile-type $\mathrm{TiO}_{2}$ : selective oxidation of thiazin dye with a bundled architecture consisting of oriented nanoneedles," Science of Advanced Materials, vol. 2, no. 1, pp. 69-73, 2010.

[8] Y. Masuda, Y. Jinbo, and K. Koumoto, "Room temperature CVD of $\mathrm{TiO}_{2}$ thin films and their electronic properties," Science of Advanced Materials, vol. 1, no. 2, p. 138, 2009. 
[9] Y. Masuda, "A special issue on applications of metal oxide nanostructures," Science of Advanced Materials, vol. 2, no. 1, pp. 1-2, 2010.

[10] Y. Masuda, "Liquid phase patterning of ceramics," Journal of the Ceramic Society of Japan, vol. 115, no. 1338, pp. 101-109, 2007.

[11] Y. Masuda, Y. F. Gao, P. X. Zhu et al., "Site-selective deposition of ceramic thin films using self-assembled monolayers," Journal of the Ceramic Society of Japan, vol. 112, no. 5, p. 1495, 2004.

[12] A. D. Handoko and G. K. L. Goh, "One-dimensional perovskite nanostructures," Science of Advanced Materials, vol. 2, no. 1, p. 16,2010 .

[13] G. Neri, "Non-conventional sol-gel routes to nanosized metal oxides for gas sensing: from materials to applications," Science of Advanced Materials, vol. 2, no. 1, pp. 3-15, 2010.

[14] A. Umar and Y.-B. Hahn, Metal Oxide Nanostructures and Their Applications, American Scientific Publishers, Calif, USA, 2009.

[15] Y. Lin, Z. Zhang, Z. Tang, F. Yuan, and J. Li, "Characterisation of $\mathrm{ZnO}$-based varistors prepared from nanometre precursor powders," Advanced Materials for Optics and Electronics, vol. 9, no. 5, pp. 205-209, 1999.

[16] G. Agarwal and R. F. Speyer, "Current change method of reducing gas sensing using $\mathrm{ZnO}$ varistors," Journal of the Electrochemical Society, vol. 145, no. 8, pp. 2920-2925, 1998.

[17] F. Quaranta, A. Valentini, F. R. Rizzi, and G. Casamassima, "Dual-ion-beam sputter deposition of $\mathrm{ZnO}$ films," Journal of Applied Physics, vol. 74, no. 1, pp. 244-248, 1993.

[18] T. Pauporté and D. Lincot, "Electrodeposition of semiconductors for optoelectronic devices: results on zinc oxide," Electrochimica Acta, vol. 45, no. 20, pp. 3345-3353, 2000.

[19] S. Ruan, "Color picture element tube for large-screen display," in Proceedings of the SPIE, vol. 262, p. 2892, 1996.

[20] Y. Nakanishi, A. Miyake, H. Kominami, T. Aoki, Y. Hatanaka, and G. Shimaoka, "Preparation of $\mathrm{ZnO}$ thin films for highresolution field emission display by electron beam evaporation," Applied Surface Science, vol. 142, no. 1-4, pp. 233-236, 1999.

[21] L. Yi, Y. Hou, H. Zhao et al., "Photo- and electro-luminescence properties of $\mathrm{ZnO}$ : $\mathrm{Zn}$ thin film,” Displays, vol. 21, no. 4, pp. 147-149, 2000.

[22] R. F. Service, "Will UV lasers beat the blues?" Science, vol. 276, no. 5314, p. 895, 1997.

[23] H. Gong, J. Q. Hu, J. H. Wang, C. H. Ong, and F. R. Zhu, "Nano-crystalline $\mathrm{Cu}$-doped $\mathrm{ZnO}$ thin film gas sensor for $\mathrm{CO}$," Sensors and Actuators, B: Chemical, vol. 115, no. 1, pp. 247251,2006

[24] W. J. Moon, J. H. Yu, and G. M. Choi, "The CO and H-2 gas selectivity of $\mathrm{CuO}$-doped $\mathrm{SnO}_{2}-\mathrm{ZnO}$ composite gas sensor," Sensors and Actuators, B: Chemical, vol. 87, no. 3, pp. 464-470, 2002.

[25] M. Law, L. E. Greene, J. C. Johnson, R. Saykally, and P. Yang, "Nanowire dye-sensitized solar cells," Nature Materials, vol. 4, no. 6, pp. 455-459, 2005.

[26] J. B. Baxter and E. S. Aydil, "Nanowire-based dye-sensitized solar cells," Applied Physics Letters, vol. 86, no. 5, Article ID 053114, pp. 1-3, 2005.

[27] R. Katoh, A. Furube, K. Hara et al., "Efficiencies of electron injection from excited sensitizer dyes to nanocrystalline $\mathrm{ZnO}$ films as studied by near-IR optical absorption of injected electrons," Journal of Physical Chemistry B, vol. 106, no. 50, pp. 12957-12964, 2002.
[28] S. Karuppuchamy, K. Nonomura, T. Yoshida, T. Sugiura, and H. Minoura, "Cathodic electrodeposition of oxide semiconductor thin films and their application to dye-sensitized solar cells," Solid State Ionics, vol. 151, no. 1-4, pp. 19-27, 2002.

[29] K. Keis, C. Bauer, G. Boschloo et al., "Nanostructured ZnO electrodes for dye-sensitized solar cell applications," Journal of Photochemistry and Photobiology A: Chemistry, vol. 148, no. 13, pp. 57-64, 2002.

[30] H. Tokudome, Y. Yamada, S. Sonezaki et al., "Photoelectrochemical deoxyribonucleic acid sensing on a nanostructured $\mathrm{TiO}_{2}$ electrode," Applied Physics Letters, vol. 87, no. 21, Article ID 213901, pp. 1-3, 2005.

[31] R. Wahab, Y.-S. Kim, D. S. Lee, J.-M. Seo, and H.-S. Shin, "Controlled synthesis of zinc oxide nanoneedles and their transformation to microflowers," Science of Advanced Materials, vol. 2, no. 1, pp. 35-42, 2010.

[32] S. K. Mohanta, D. C. Kim, B. H. Kong, H. K. Cho, W. Liu, and S. Tripathy, "Optical properties of $\mathrm{ZnO}$ nanorods and hybrid structures grown on p-type GaN/sapphire and siliconon-insulator substrates," Science of Advanced Materials, vol. 2, no. 1, pp. 64-68, 2010.

[33] D. W. Chu, Y. Masuda, T. Ohji, and K. Kato, "Formation and photocatalytic application of $\mathrm{ZnO}$ nanotubes using aqueous solution," Langmuir, vol. 26, no. 4, pp. 2811-2815, 2010.

[34] X. L. Hu, Y. Masuda, T. Ohji, and K. Kato, "Micropatterning of $\mathrm{ZnO}$ nanoarrays by forced hydrolysis of anhydrous zinc acetate," Langmuir, vol. 24, no. 14, pp. 7614-7617, 2008.

[35] Y. Masuda, N. Kinoshita, F. Sato, and K. Koumoto, "Site-selective deposition and morphology control of UV- and visiblelight-emitting ZnO crystals," Crystal Growth and Design, vol. 6, no. 1, pp. 75-78, 2006.

[36] Y. Masuda, N. Kinoshita, and K. Koumoto, "Hexagonal symmetry radial whiskers of ZNO crystallized in aqueous solution," Journal of Nanoscience and Nanotechnology, vol. 9, no. 1, pp. 522-526, 2009.

[37] Y. Masuda and K. Kato, "Morphology control of zinc oxide particles at low temperature," Crystal Growth and Design, vol. 8, no. 8, pp. 2633-2637, 2008.

[38] Y. Masuda and K. Kato, "High c-axis oriented stand-alone ZnO self-assembled film," Crystal Growth and Design, vol. 8, no. 1, pp. 275-279, 2008.

[39] Y. Masuda and K. Kato, "Rapid growth of thick particulate film of crystalline $\mathrm{ZnO}$ in an aqueous solution," Thin Solid Films, vol. 516, no. 9, pp. 2474-2477, 2008.

[40] Y. Masuda, T. Sugiyama, H. Lin, W. S. Seo, and K. Koumoto, "Selective deposition and micropatterning of titanium dioxide thin film on self-assembled monolayers," Thin Solid Films, vol. 382, no. 1-2, pp. 153-157, 2001.

[41] Y. Masuda, Y. Jinbo, T. Yonezawa, and K. Koumoto, “Templated site-selective deposition of titanium dioxide on selfassembled monolayers," Chemistry of Materials, vol. 14, no. 3, pp. 1236-1241, 2002.

[42] Y. Masuda, T. Sugiyama, and K. Koumoto, "Micropatterning of anatase $\mathrm{TiO}_{2}$ thin films from an aqueous solution by a siteselective immersion method," Journal of Materials Chemistry, vol. 12, no. 9, pp. 2643-2647, 2002.

[43] Y. Masuda, S. Ieda, and K. Koumoto, "Site-selective deposition of anatase $\mathrm{TiO}_{2}$ in an aqueous solution using a seed layer," Langmuir, vol. 19, no. 10, pp. 4415-4419, 2003.

[44] Y. Masuda, N. Saito, R. Hoffmann, M. R. de Guire, and K. Koumoto, "Nano/micro-patterning of anatase $\mathrm{TiO}_{2}$ thin film 
from an aqueous solution by site-selective elimination method," Science and Technology of Advanced Materials, vol. 4, no. 5, pp. 461-467, 2003.

[45] Y. Masuda and K. Kato, "Aqueous synthesis of $\mathrm{ZnO}$ rod arrays for molecular sensor," Crystal Growth and Design, vol. 9, no. 7, pp. 3083-3088, 2009. 

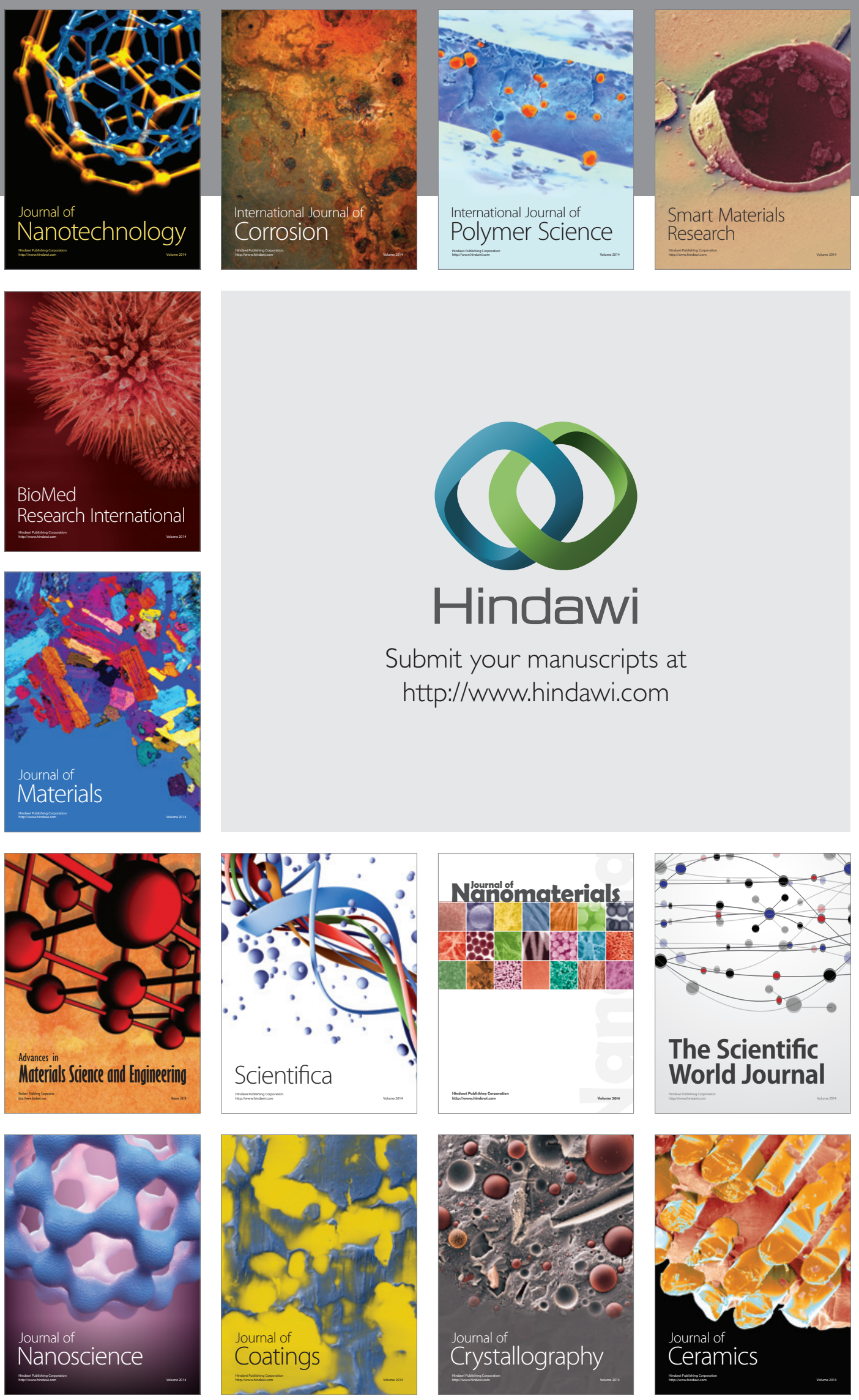

The Scientific World Journal

Submit your manuscripts at

http://www.hindawi.com

\section{World Journal}

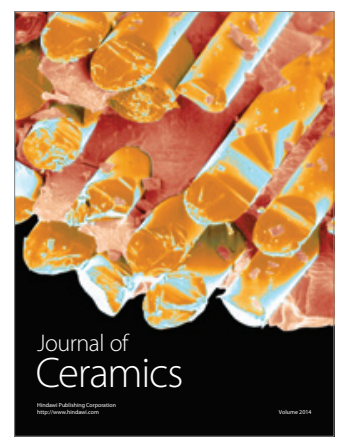

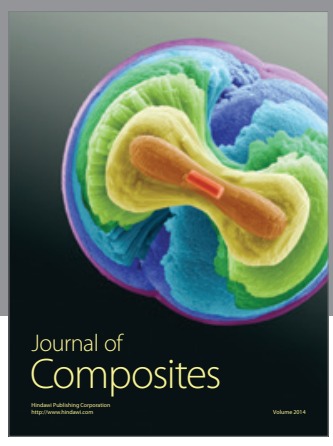
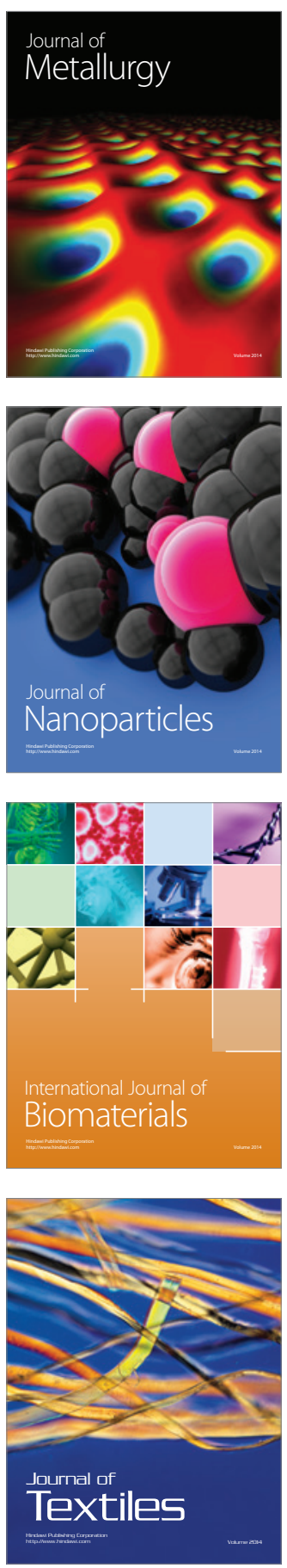